\title{
Antiproliferative effects of Tubi-bee propolis in glioblastoma cell lines
}

\author{
Kleiton Silva Borges ${ }^{1}$, María Sol Brassesco ${ }^{2}$, Carlos Alberto Scrideli ${ }^{2}$, Ademilson Espencer Egea Soares ${ }^{1}$ \\ and Luiz Gonzaga Tone ${ }^{1,2}$ \\ ${ }^{1}$ Departamento de Genética, Faculdade de Medicina de Ribeirão Preto, Universidade de São Paulo, \\ Ribeirão Preto, SP, Brazil. \\ ${ }^{2}$ Divisão de Pediatria Oncológica, Departamento de Pediatria, Escola de Medicina de Ribeirão Preto, \\ Universidade de São Paulo, Ribeirão Preto, SP, Brazil.
}

\begin{abstract}
Propolis is a resin formed by a complex chemical composition of substances that bees collect from plants. Since ancient times, propolis has been used in folk medicine, due to its biological properties, that include antimicrobial, anti-inflammatory, antitumoral and immunomodulatory activities. Glioblastoma is the most common human brain tumor. Despite the improvements in GBM standard treatment, patients' prognosis is still very poor. The aim of this work was to evaluate in vitro the Tubi-bee propolis effects on human glioblastoma (U251 and U343) and fibroblast (MRC-5) cell lines. Proliferation, clonogenic capacity and apoptosis were analyzed after treatment with $1 \mathrm{mg} / \mathrm{mL}$ and $2 \mathrm{mg} / \mathrm{mL}$ propolis concentrations for different time periods. Additionally, glioblastoma cell lines were submitted to treatment with propolis combined with temozolomide (TMZ). Data showed an antiproliferative effect of tubi-bee propolis against glioblastoma and fibroblast cell lines. Combination of propolis with TMZ had a synergic antiproliferative effect. Moreover, propolis caused decrease in colony formation in glioblastoma cell lines. Propolis treatment had no effects on apoptosis, demonstrating a cytostatic action. Further investigations are needed to elucidate the molecular mechanism of the antitumor effect of propolis, and the study of its individual components may reveal specific molecules with antiproliferative capacity.
\end{abstract}

Key words: glioblastoma, propolis, temozolomide, U251, U343.

Received: August 6, 2010; Accepted: February 4, 2011.

Propolis is a resinous product composed of various botanical exudates, collected from plants and used by bees as a protective hive barrier against different pathogens. Its chemical composition includes flavonoids, aromatic acids, esters, aldehydes, ketones, fatty acids, terpenes, steroids, amino acids, polysaccharides, hydrocarbons, alcohols, hydroxybenzene, and several other compounds in trace amounts (Bankova et al., 1983; Marcucci, 1995). Its composition varies according to the resin sources in the hive specific region. Propolis has been widely used in folk medicine, with therapeutic or preventive effects against inflammation, heart disease, diabetes mellitus, microbial hepatotoxicity and cancer (Bankova et al., 1998; Burdock, 1998).

Glioblastoma is the most frequent and aggressive primary brain tumor in adults. Despite standard treatments, consisting of surgery and postoperative radiotherapy, patient survival remains poor, mainly attributed to tumor-

Send correspondence to Kleiton Silva Borges. Laboratório de Pediatria, Faculdade de Medicina de Ribeirão Preto, Hospital das Clínicas, Universidade de São Paulo, Bloco G, Av. Bandeirantes 3900, 14048-900 Ribeirão Preto, SP, Brazil. E-mail: ksborges@usp.br. inherent radio- and chemoresistance (Esteller et al., 2000; Scrideli et al., 2008). In recent years, the combination of the alkylating agent temozolomide (TMZ) with standard daily fractionated irradiation therapy followed by adjuvant TMZ have shown to improve prognosis, therefore becoming a part of the standard therapy for patients with newly diagnosed glioblastoma (van Nifterik et al. 2007; Brandes et al., 2010). This chemotherapeutic pro-drug is transformed under physiological conditions into its active unstable methylating metabolite, 5-(3-methyl-1-triazeno)imidazole-4-carboxamide (MTIC). Methylation of the DNA by MTIC results in $\mathrm{O}^{6}$-methylguanine adducts, which are considered to be responsible for the cytotoxic effect of TMZ (Esteller et al., 2000; Brandes et al., 2010). $\mathrm{O}^{6}$-methylguanine adducts can result in futile attempts of the mismatch repair system, leading to DNA double-strand breakage and eventually cell death (van Nifterik et al., 2007)

Several reports have shown the antiproliferative effects of propolis from different origins and their fractions in several cancer cell lines (Grunberger et al., 1988; Khalil, 2006). In the present study, we describe the anti-cancer effects of ethanolic propolis extract produced by Scaptotrigona sp (Tubi-bee propolis) in glioblastoma cell 
lines, associated or not with TMZ, and in one non-neoplastic fibroblast cell line.

Propolis samples obtained from the stingless "Tubi" beehives (Scaptotrigona sp) were collected in the Serra do Corda region (Maranhão State, Brazil). Tubi-bee propolis extracts were obtained as previously described (Farnesi et al., 2009). Briefly, propolis was ground and an ethanol extract was prepared, as follows: $30 \mathrm{~g}$ of propolis $/ 100 \mathrm{~mL}$ ethanol $(70 \%)$. The solution was kept at room temperature for 20 days and shaken once a day. After filtration, the solvent was totally evaporated in a water bath, at temperatures not exceeding $50{ }^{\circ} \mathrm{C}$. For cell assays the crude extract was diluted in dimethylsulphoxide (DMSO, Sigma-Aldrich).

TMZ, known commercially as Temodal ${ }^{\circledR}$, was acquired from Schering-Plough Brazil and diluted according to the manufacturer's instructions. The capsule content was diluted in water at a ratio of $22 \mathrm{mg}$ drug $/ 100 \mathrm{~mL}$ water. This solution was placed in a shaker for $30 \mathrm{~min}$ at $37^{\circ} \mathrm{C}$ and then filtered through a Millipore ${ }^{\circledR}$ filter $(0.5 \mu \mathrm{m})$. By this procedure, $85 \%$ of dissolved active principle was obtained. Aliquots of the drug were stored at $-20^{\circ} \mathrm{C}$. TMZ concentrations of 20,50 and $100 \mu \mathrm{M}$ were used in the experiments.

Human adult glioblastoma cell lines U251 and U343 and the human fibroblast cell line MRC5 were purchased from the American Type Culture Collection. Cells were cultured in HAM F10 medium (Gibco BRL, Life Technologies ${ }^{\circledR}$, Carlsbad, CA, USA) supplemented with $10 \%$ fetal bovine serum, penicillin $(100 \mathrm{U} / \mathrm{mL})$ and streptomycin $(100 \mu \mathrm{g} / \mathrm{mL})$, at $37{ }^{\circ} \mathrm{C}$ in a humidified $5 \% \mathrm{CO}_{2}$ incubator.

The effects of propolis on clonogenic capacity were evaluated by a clonogenic assay (Franken et al., 2006). After trypsinization, single cell suspensions of 300 cells were seeded into 6-well plates and treated with propolis extract at the concentrations of 1 and $2 \mathrm{mg} / \mathrm{mL}$ for $48 \mathrm{~h}$. After this treatment, the culture medium was removed and replaced with extract-free medium. The cell cultures were then incubated for 7-10 days and thereafter the colonies were rinsed with PBS, fixed with methanol and stained with Giemsa. All colonies with $>50$ cells were counted. Assays were performed in triplicate.

For the proliferation assay, cells were seeded on 96well plates $\left(1 \times 10^{3}\right.$ cells/well). After $24 \mathrm{~h}$, the medium was replaced with fresh media containing the treatment (propolis, TMZ or DMSO at $0,5 \%$ ) and then cultured for 24,48 and $72 \mathrm{~h}$. After the treatment, the culture medium was removed and replaced with medium containing $10 \mu \mathrm{L}$ of XTT dye $(3 \mathrm{mg} / \mathrm{mL}$ ) (XTT II; Roche Molecular Biochemicals, Indianapolis, USA) in each well. The plates were incubated for $2 \mathrm{~h}$ at $37^{\circ} \mathrm{C}$, and the formazan product was measured at $450 \mathrm{~nm}$ in an iMark microplate reader (Bio-Rad Laboratories). All experiments were performed in triplicate. Values are shown as mean \pm SD.

For apoptosis assessment, a total of $3 \times 10^{5}$ cells were seeded in $25 \mathrm{~cm}^{2}$ tissue culture flasks containing $5 \mathrm{~mL}$ of culture medium. After $24 \mathrm{~h}$, the medium was replaced, propolis and DMSO were added, and then the cells were cultured for additional $48 \mathrm{~h}$. Apoptotic cells were recognized by nuclear condensation and fragmentation, according to Lee and Shacter (1999). Treated cells were centrifuged and incubated for $5 \mathrm{~min}$ at $37^{\circ} \mathrm{C}$ with bisbenzimide (Hoechst 33342), propidium iodide and fluorescein diacetate (Sigma Chemical Co., St. Louis, USA). Then, samples were mounted on slides, coverslipped and analyzed by fluorescence microscopy with a triple filter. Cells were scored and categorized according to differential staining: (1) normal: blue nucleus and green cytoplasm, (2) apoptotic: fragmented blue nucleus and green cytoplasm, and (3) necrotic: spherical red nucleus. 500 nuclei were analyzed per treatment.

One-way or two-way ANOVA followed by the appropriate post-hoc test (Bonferroni) were used to check for significant differences between groups (differences between doses or times). Differences were considered significant at $\mathrm{p}<0.05$.

To determine the TMZ concentration for combination with propolis, U343 and U251 cells were submitted to different concentrations of TMZ for 24, 48 and $72 \mathrm{~h}$. The TMZ concentration chosen for combined treatment was $50 \mu \mathrm{M}$, which reduced proliferation at $48 \mathrm{~h}$ for U251 and U343 cell lines (Figure 2).

U251, U343 and MCR-5 cell lines were treated with propolis extract at the concentrations of 1 and $2 \mathrm{mg} / \mathrm{mL}$ for 24, 48 and $72 \mathrm{~h}$. The glioblastoma cell lines were also treated with a propolis concentration of $2 \mathrm{mg} / \mathrm{mL}$ associated with $50 \mu \mathrm{M}$ of temozolomide. Cell viability was determined by an XTT assay, as described above.

Propolis extract concentrations inhibited growth of the three cell lines when compared with DMSO $(0.5 \%)$ $(\mathrm{p}<0.05)$ (Figure 1). For cell line U251, proliferation inhibition was observed at 24,48 and $72 \mathrm{~h}$ corresponding to a 10,24 and $46 \%$ decrease with the $1 \mathrm{mg} / \mathrm{mL}$ dose, and a 15 , 32 and $59 \%$ decrease with the $2 \mathrm{mg} / \mathrm{mL}$ dose, respectively. However, there was no statistically significant difference between the concentrations for this cell line at the times studied (Figure 1A).

In cell line U343, a decrease in proliferation was observed at 24,48 and $72 \mathrm{~h}$ for both dosages, corresponding to a 14, 21 and $30 \%$ decrease for the $1 \mathrm{mg} / \mathrm{mL}$, and a 30,42 and $48 \%$ decrease for the $2 \mathrm{mg} / \mathrm{mL}$ dose. For this cell line, all treatments except the $72 \mathrm{~h}$ treatment showed statistically significant differences between the concentrations (Figure $1 \mathrm{~B})$.

Statistically significant effects of dose and time dependence were observed only for the U343 cell line $(\mathrm{p}<0.05)$. The association of propolis and TMZ showed a synergistic effect on both glioblastoma cell lines at all times analyzed, except for the U343 cell line at $72 \mathrm{~h}$ (Figure 1A and B). In the fibroblast MRC-5 cell line a decrease in proliferation was also observed, although this effect was neither dose- nor time-dependent (Figure 1C). 


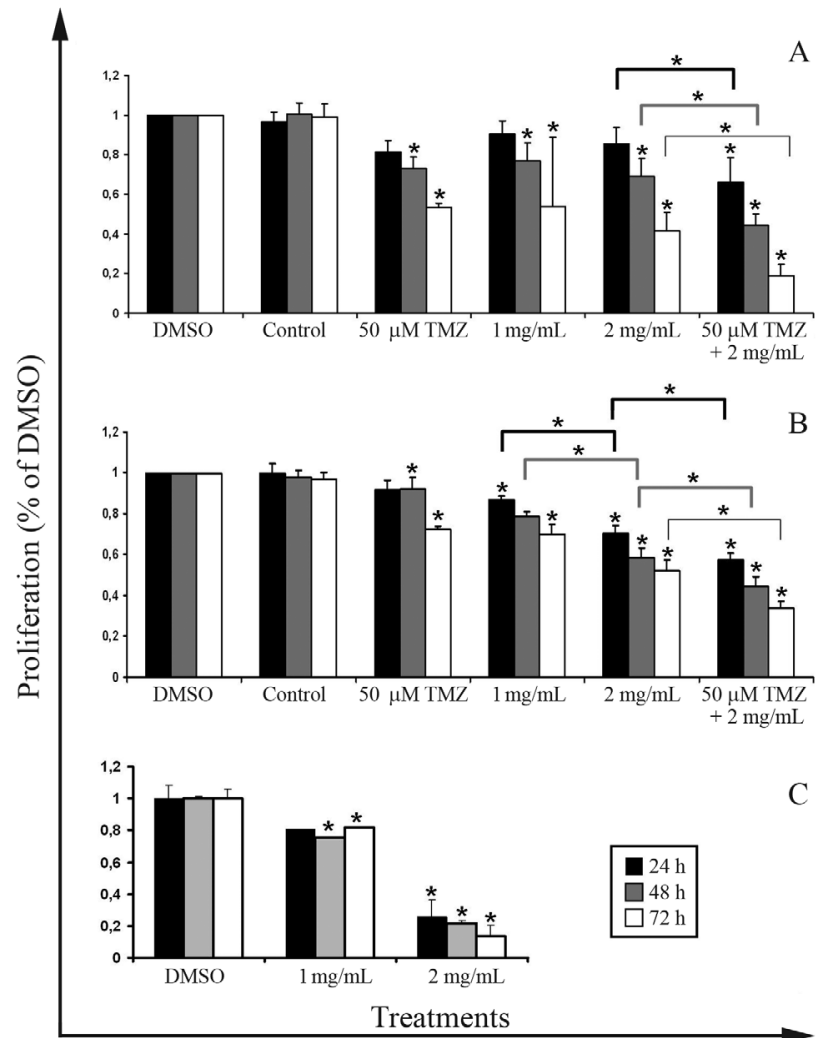

Figure 1 - Proliferation assay of cell lines treated with Tubi-bee propolis at the concentrations of 1 and $2 \mathrm{mg} / \mathrm{mL}$ for 24,48 and $72 \mathrm{~h}$. Glioblastoma cells were also treated with temozolomide (TMZ) combined with propolis. Asterisks indicate a statistically significant difference between groups. A. U251, B. U343, C. MRC5.

In both the U251 and U343 cell lines treated with 1 and $2 \mathrm{mg} / \mathrm{mL}$ propolis extract for $48 \mathrm{~h}$, a decrease in colony formation capacity was observed; however, there was no difference between the two treatments (data not shown).

To determine the occurrence of apoptosis in GBM cells treated with the propolis extract, the cells were differentially stained. Apoptosis was not observed after the treatment with propolis at neither of the concentrations tested. The methodology applied also allowed the detection of necrotic cells, observed at a low number and without differences between treatments (data not shown).

Propolis, a complex mixture of plant metabolites, shows a broad spectrum of biological activities including antibiotic, antioxidative, anti-inflammatory and anticancer effects (Bankova et al., 1983; Marcucci, 1995; Banskota et al., 2001). Its cytotoxicity in cultures of human and animal tumor cells, including breast carcinoma, melanoma, colon and renal carcinoma cell lines, has been frequently reported in the literature (Khalil, 2006).

The present study showed that propolis extract inhibited proliferation in glioblastoma and fibroblast cell lines, as already demonstrated by previous studies. Propolis extract from the Netherlands showed an interesting antiproliferative activity against highly metastatic liver murine

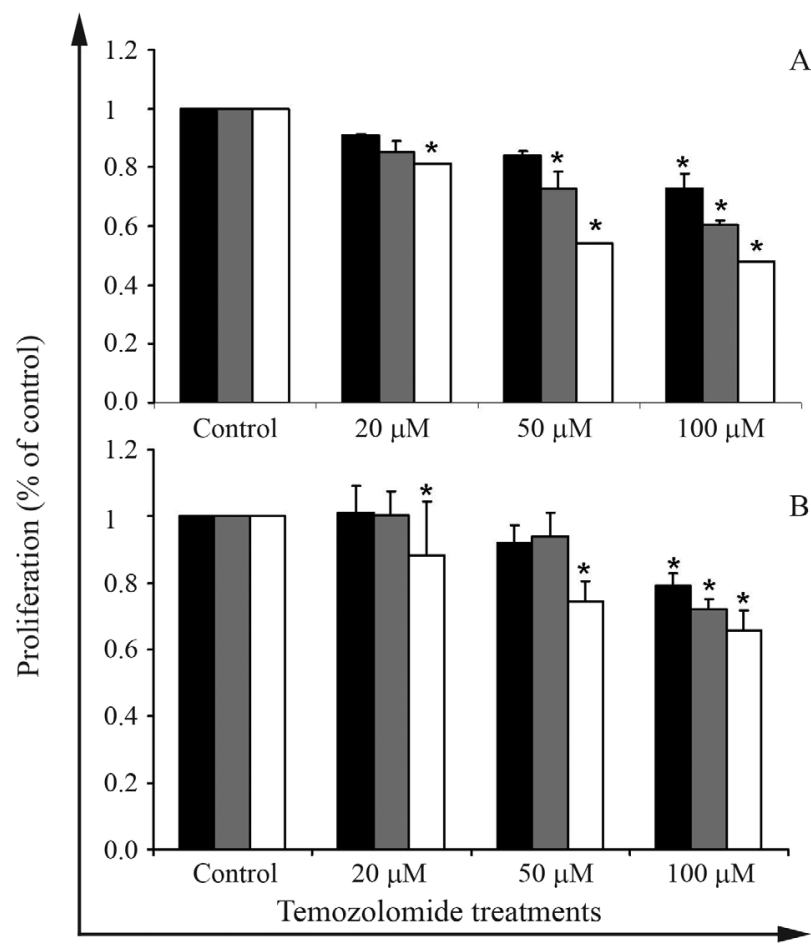

Figure 2 - Proliferation assay of cell lines treated with TMZ at the concentrations of 20,50 and $100 \mu \mathrm{M}$, for 24,48 and $72 \mathrm{~h}$. Asterisks indicates a statistically significant difference between the TMZ-treated and the control group.

colon 26-L5 carcinoma cells (Banskota et al., 2000). A butanolic Greek propolis extract was also found to be cytotoxic in two malignant human cell lines (HT-1080 fibrosarcoma and HT-29 colon adenocarcinoma), whereas it was not equally toxic when tested in normal human skin fibroblasts (Pratsinis et al., 2010).

In cell line U343, the antiproliferative effect of propolis was dose- and time-dependent, suggesting that this cell line is more sensitive than U251 that did not present the same effect. These differences could be associated with $p 53$ status (mutant or wild type). Cell line U343, but not U251, carries the wild type gene (Ishii et al., 1999) and the antiproliferative effects of propolis may be $p 53$-dependent. Other studies have shown increased expression of $p 53$ after treatment with different propolis extracts (Weng et al., 2007; Ishihara et al., 2009; Xuan et al., 2010). Several functions and activities are attributed to p53, and it also acts in different cellular metabolism processes, such as cell cycle, apoptosis, senescence and DNA repair (Joerger and Fersht, 2008).

The combination of propolis with temozolomide, a chemoterapeutic drug used in the treatment of glioblastoma which produces DNA alkylation (Esteller et al., 2000), evidenced synergistic antiproliferative effects, demonstrating the ability of propolis to predispose cells to the action of chemotherapy (Figures 1A and B). However, this effect should be further investigated. 
The effects observed in this work can be related with the chemical composition of propolis, which is highly dependent on the flora of the region where it is collected. Sawaya et al. (2009) studied the same Tubi-bee propolis used in this work and showed that its composition varied seasonally. The mass spectra ions found in this extract were $\mathrm{m} / \mathrm{z} 371,373,401$ and 471 . This latter was the more important one; its formula $\mathrm{C}_{30} \mathrm{H}_{47} \mathrm{O}_{4}$ suggests that it has at least one acid function. Electrospray Ionization - Mass Spectrometry (ESI-MS) of these ions showed to be compatible with terpenes and with acid groups. All are marker ions of Schinus terebenthifolius, also known in Brazil as "aroeira mansa", a preferred source of resins in stingless bee propolis in many regions of Brazil.

Propolis from temperate zones predominantly contains phenolic compounds, including flavonoids and cinnamic acid derivatives (Marcucci, 1995). On the other hand, diterpenes and prenylated compounds, which are virtually absent in propolis from temperate zones, have been reported to be the major constituents of propolis from tropical South America, along with lignans, flavonoids and other classes of compounds (Sawaya et al., 2009).

Several reports have shown apoptosis induction caused by propolis extracts (Weng et al., 2007; Szliszka et al., 2009; Xuan et al., 2010). However, in the present study, this effect was not observed, suggesting that in the concentrations used this type of propolis presents only cytostatic effects.

In summary, this investigation of the potential antiproliferative effects of propolis in human glioblastoma and normal fibroblast cell lines showed a strong inhibitory effect on the proliferation of all cell lines tested. Dose and time dependence were only observed for cell line U343. Moreover, the association of propolis with temozolomide produced synergistic antiproliferative effects. Propolis treatment also inhibited the clonogenic capacity in GBM cell lines, but the antitumor effects observed here were not caused by apoptosis. Further investigations are needed to elucidate the molecular mechanism of the antitumor effect of propolis, and the study of its individual constituents may reveal specific molecules with antiproliferative capacity.

\section{Acknowledgments}

Financial Support by Fundação de Amparo a Pesquisa do Estado de São Paulo (FAPESP, process $n^{\circ}$ 2009/50118-2), and FAPESP fellowships to KSB (2010/08699-5) and MSB (2006/04827-3) are acknowledged

\section{References}

Bankova VS, Popov SS and Marekov NL (1983) A study on flavonoids of propolis. J Nat Prod 46:471-474.

Bankova V, Boudourova-Krasteva G, Popov S, Sforcin JM and Funari SRC (1998) Seasonal variations of the chemical composition of Brazilian propolis. Apidologie 29: 361-36.
Banskota AH, Tezuka Y, Adnyana IK, Midorikawa K, Matsushige K, Message D, Huertas AA and Kadota S (2000) Cytotoxic, hepatoprotective and free radical scavenging effects of propolis from Brazil, Peru, the Netherlands and China. J Ethnopharmacol 72:239-246.

Banskota AH, Tezuka Y and Kadota S (2001) Recent progress in pharmacological research of propolis. Phytother Res 15:561-571.

Brandes AA, Franceschi E, Tosoni A, Bartolini S, Bacci A, Agati R, Ghimenton C, Turazzi S, Talacchi A, Skrap M, et al. (2010) O(6)-methylguanine DNA-methyltransferase methylation status can change between first surgery for newly diagnosed glioblastoma and second surgery for recurrence: clinical implications. Neuro Oncol 12:283-288.

Burdock GA (1998) Review of the biological properties and toxicity of bee propolis (propolis). Food Chem Toxicol 36:347-363.

Esteller M, Garcia-Foncillas J, Andion E, Goodman SN, Hidalgo OF, Vanaclocha V, Baylin SB and Herman JG (2000) Inactivation of the DNA-repair gene MGMT and the clinical response of gliomas to alkylating agents. N Engl J Med 343:1350-1354.

Farnesi AP, Aquino-Ferreira R, De Jong D, Bastos JK and Soares AEE (2009) Effects of stingless bee and honey bee propolis on four species of bacteria. Genet Mol Res 8:635-640.

Franken NA, Rodermond HM, Stap J, Haveman J and van Bree C (2006) Clonogenic assay of cells in vitro. Nat Protoc 1:2315-2139.

Grunberger D, Banerjee R, Eisinger K, Oltz EM, Efros L, Caldwell M, Estevez V and Nakanishi K (1988) Preferential cytotoxicity on tumor cells by caffeic acid phenethyl ester isolated from propolis. Experientia 44:230-232.

Ishihara M, Naoi K, Hashita M, Itoh Y and Suzui M (2009) Growth inhibitory activity of ethanol extract of Chinese and Brazilian propolis in four human colon carcinoma cell lines. Oncol Rep 22:349-354.

Ishii N, Maier D, Merlo A, Tada M, Sawamura Y, Diserens AC and Van Meir EG (1999) Frequent co-alterations of TP53, p16/CDKN2A, p14ARF, PTEN tumor suppressor genes in human glioma cell lines. Brain Pathol 9:469-479.

Joerger AC and Fersht AR (2008) Structural biology of the tumor suppressor p53. Annu Rev Biochem 77:557-582.

Khalil ML (2006) Biological activity of bee propolis in health and disease. Asian Pac J Cancer Prev 7:22-31.

Lee Y and Shacter E (1999) Oxidative stress inhibits apoptosis in human lymphoma cells. J Biol Chem 274:19792-19798.

Marcucci MC (1995) Propolis: Chemical composition, biological properties and therapeutic activity. Apidologie 26:83-99.

Pratsinis H, Kletsas D, Melliou E and Chinou I (2010) Antiproliferative activity of Greek propolis. J Med Food 13:286290.

Sawaya ACHF, Calado JCP, Santos LC, Marcucci MC, Akatsu IP, Soares AEE, Abdelnur PV, Cunha IBSC and Eberlin MN (2009) Composition and antioxidant activity of propolis from three species of Scaptotrigona stingless bees. J Apiprod ApiMed Sci 1:37-42.

Scrideli CA, Carlotti CG Jr, Okamoto OK, Andrade VS, Cortez MA, Motta FJ, Lucio-Eterovic AK, Neder L, Rosemberg S, Oba-Shinjo SM, et al. (2008) Gene expression profile analysis of primary glioblastomas and non-neoplastic brain tissue: identification of potential target genes by oligonucleotide 
microarray and real-time quantitative PCR. J Neurooncol 88:281-91.

Szliszka E, Czuba ZP, Bronikowska J, Mertas A, Paradysz A and Krol W (2009) Ethanolic extract of propolis augments TRAIL-induced apoptotic death in prostate cancer cells. Evid Based Complement Alternat Med, Ahead-of-Print, doi:10.1093/ecam/nep180.

van Nifterik KA, van den Berg J, Stalpers LJ, Lafleur MV, Leenstra S, Slotman BJ, Hulsebos TJ and Sminia P (2007) Differential radiosensitizing potential of temozolomide in MGMT promoter methylated glioblastoma multiform cell lines. Int J Radiat Oncol Biol Phys 69:1246-1253.
Weng MS, Liao CH, Chen CN, Wu CL and Lin JK (2007) Propolin $\mathrm{H}$ from Taiwanese propolis induces $\mathrm{Gl}$ arrest in human lung carcinoma cells. J Agric Food Chem 55:52895298.

Xuan H, Zhao J, Miao J, Li Y, Chu Y and Hu F (2010) Effect of Brazilian propolis on human umbilical vein endothelial cell apoptosis. Food Chem Toxicol 49:78-85.

Associate Editor: Emmanuel Dias Neto

License information: This is an open-access article distributed under the terms of the Creative Commons Attribution License, which permits unrestricted use, distribution, and reproduction in any medium, provided the original work is properly cited. 